перевода иноязычных вкраплений представляет также значительный интерес, поскольку иноязычные элементы по-разному воспринимаются в разных культурах. С трудностями перевода иноязычной лексики ежедневно сталкиваются переводчикипрактики, на ней же останавливают теоретики перевода. Иноязычные вкрапления - это живой способ расширения фразеологического запаса национального языка. Данные языковые элементы, присущие литературному языку всех стран мира, насыщают произведения средствами стилистической выразительности, позволяют создать колорит, специфическую атмосферу и учувствуют в формировании речевой характеристики персонажей.

$$
* * *
$$

1. Алексеева, И.С. Введение в переводоведение. Учеб. пособие для студ. филол. и лингв фак. высш. учеб. заведений. / И.С. Алексеева. - СПб.: Филологический факультет СПбГУ; М.: Издательский центр «Академия», 2004. - 352 с.

2. Влахов, С. И., Флорин С. П. Непереводимое в переводе. - М., Валент: 2012.4. Казакова, Т. А. Практические основы перевода. English $\leftrightarrow$ Russian /T. А. Казакова - СПб.: Союз, 2010. - 320 c.

3. Листрова-Правда, Ю.Т. Отбор и употребление иноязычных вкраплений в русской литературной речи XIX века. Воронеж: Изд. Воронежского ун-та. 1986.

4. Робертс Г.Д. Шантарам. Том 1 / Г.Д. Робертс. - СПб.: изд. на русском языке, ООО «Издательская Группа «Азбука-Аттикус»»», 2013. - 602 с.

5. Робертс, Г.Д. Шантарам. Том 2 / Г.Д. Робертс. - СПб.: изд. на русском языке, ООО «Издательская Группа «Азбука-Аттикус»»), 2013. - 476 с.

6. Толстой, Л.Н. Полное собрание романов и повестей в двух томах. Том 1. - М.: «Издательство АЛЬФА-КНИГА», 2009. -1279с.: ил. - (Полное собрание в двух томах).

7. Gregory David Roberts Shantaram published in Great Britain by ABSCUS, 2004. p.933.

\title{
Рахматуллина Г.М. \\ Лексические особенности авторского стиля Х. Филдинг и способы его передачи при переводе (на примере романа Х. Филдинг “Дневник Бриджит Джонс")
}

\author{
Сургутский государственный университет \\ (Россия, Сургут)
}

doi: $10.18411 / s p c-26-03-2018-09$

idsp: 000001:spc-26-03-2018-09

Литературное произведение отражает действительность настолько, насколько это позволяет ему то, кто его создал. Любой текст начинается с автора, так как именно автор, соединяя различные элементы, создает то или иное произведение. Как считает Д.С. Лихачев, «внутренний мир художественного произведения представляет взаимосвязанные закономерности, собственные измерения и собственный смысл как система. Внутренний мир художественного произведения существует не сам по себе и не для самого себя. Он не автономен. Он зависит от реальности, “отражает" мир действительности. Однако то преобразование мира, которое допускает художественное произведение, имеет целостный и целенаправленный характер. Преобразование действительности связано с идеей произведения, с теми задачами, которые художник ставит перед собой» [Цит. по Романова, 2006].

Понятие «индивидуальный авторский стиль» не имеет чёткого определения или даже описания, несмотря на то, что исследователи-лингвисты и литературоведы занимаются этим вопросом не одно десятилетие.

Тому, как функционируют различные виды текстов и лингвистические способы выражения их особенностей, посвящены множество исследований. Изучение текста направлено на выявление языковых особенностей разных частей текста, которые функционируют между собой на разных уровнях. Изучением данных вопросов занимались как отечественные (Л. Бабенко, Н. Болотнова, И. Гальперин, В. Одинцов, 3. Тураева, и др.) так и зарубежные (Р. Барт, Р. Харверт, А. Хилл) исследователи.

Впервые авторский стиль, обозначаемый как отдельная категория художественной литературы, был представлен в работах В. Виноградова. Он 
определяет его как «уникальный, исторически обусловленный, сложный компонент, но такой, который представляет собой структурное единство средств и форм системы словесных выражений в его развитии» [Виноградов, 1961]. Это определение очень похоже на определение идиостиля А. Федорова. Он отмечает это как «систему языковых средств, которая формируется и используется автором при создании художественной литературы». В. Пищальникова понимает индивидуальный стиль как методы использования и приемы функциональных преобразований языковых единиц в вымышленные элементы, унаследованные ко всему творчеству автора [Пищальникова, 1984]. Они также имеют системный и регулярный характер. О. Ефимов утверждает, что авторский стиль - это прямое, естественное авторское умение использовать слова в определенном значении, выражать кратко, чтобы передать многое, быть лаконичным, но говорить все, объединять идею и форму плотно, быть оригинальным в личности автора и ум"[Ефимов, 1961].

Индивидуальность автора проявляется, как и утверждал М. М. Бахтин:

1) в выборе темы, содержательном компоненте;

2) в отборе языковых средств,

3) в композиции произведения. [Бахтин, 1979]

В целом индивидуальный стиль каждого человека обусловлен такими факторами, как:

1) доминирующие свойства познавательного стиля (преимущественно аналитический или синтезирующий характер, степень дифференциации понятий, ригидность/гибкость связей при формировании содержания понятия и др.);

2) 2свойства стиля мышления (понятийное или образное, негативнооценочное либо толерантное, экстравертное или интровертное и т.д.);

3) объективированность ("рафинированность") либо субъективированность изложения, что приводит к использованию определенных речевых жанров;

4) языковая компетенция автора, причем не только в отношении степени владения синонимическим богатством языка, но и в плане творческой способности ориентировать языковые единицы на возможно более точное выражение тех или иных "квантов" смысла, а также движение содержания от незнания к знанию;

5) прагматическая установка на коммуникацию с читателем и т.д. [Цит. по Бахтин, 1979]

Основу для будущего женской литературы заложили британские писательницы, такие как Джейн Остин, Шарлотта и Эмили Бронте, Элизабет Гаскелл. Их работы оказали огромное влияние на целое поколение как читательниц, так и писательниц. Одной из них является Хелен Филдинг (“Дневник Бриджит Джонс”, “Оливия Джоулз” и др.), чьи произведения дали старт новому течению в литературе -. что дословно можно перевести как “литература для цыпочек”, то есть литература, создаваемая для женщин. Одним из самых известных произведений в жанре чиклит является роман Хелен Филдинг “Дневник Бриджит Джонс”. Главная героиня любого произведения данного жанра - современная женщина, именно это и является причиной успеха этих книг. Классические женские романы читательницам трудно сопоставить с жизнью, в то время как чиклит описывает таких же женщин, как они сами, что делает эти произведения более реалистичными. “Дневник Бриджит Джонс" ведет повествование от первого лица, что ещё больше сближает читательниц с главной героиней и вызывает чувство огромное сопереживания.

Романы о Бриджит Джонс стали очень популярны, несмотря на то, что идея повествования о жизни одинокой женщины не нова. Секрет заключается в индивидуальном авторском стиле, который присущ Хелен Филдинг. Среди 
характерных стилистических особенностей её произведений можно выделить следующие:
1) аллюзии;
2) окказионализмы;
3) сокращения;
4) опущения.

Рассмотрим указанные явление и способы их передачи при переводе более подробно. Автором русскоязычного перевода является А.Н. Москвичёва.

Ярким примером аллюзии в романе “Дневник Бриджит Джонс" является отсылка к роману Джейн Остин "Гордость и предубеждение”. Ухажёра Бриджит Джонс зовут мистер Марк Дарси, - его фамилия совпадает с фамилией главного героя романа Джейн Остин. Такая аллюзия предполагает, что читатели уже знакомы с этим произведением и смогут провести аналогию между сюжетными линиями двух романов.

Ещё одной особенностью романа “Дневник Бриджит Джонс" является использование окказионализмов. Частое их употребление обусловлено формой произведения - формой личного дневника. В классическом художественном произведении окказионализмы встречаются намного реже, так как текст проверяется и перепроверяется автором много раз, и каждый раз он что-то меняет в своей работе, делая текст более ладным. Хелен Филдинг намеренно использует окказионализмы, потому что они придают повествованию элемент спонтанности, естественности. Читатель воспринимает Бриджит как живого человека, для которого смысл фразы важнее его литературной формы. Одним из примеров окказионализмов является слово "entire-tune-of-town-hall clock doorbell", которое А.Н. Москвичёва перевела как "кнопку звонка, исполнившего целиком мелодию городских курантов”. Переводчица прибегла к использованию причастного оборота, что помогло ей сохранить смысл окказионализма, но не позволило передать именно саму ситуацию его случайного возникновения. Некоторые окказионализмы, такие как, например, "divorced-by-cruel-wife Mark" Москвичёва переводит окказионализм буквально, не прибегая к изменению формы: “разведённый-со-злой-женой Марк”. В этом случае перевод окказионализма с помощью причастия не вынуждает изменять форму слова, так как в оригинале Хелен Филдинг тоже присутствует причастие "divorced".

Выделяется также и другая особенность романа - наличие большого количества сокращений. В большинстве случаев Бриджит Джонс применяет сокращения, например, вместо “very" - "v.”, вместо "good" - "g.". В переводе Москвичёва передаёт это тоже путём сокращения слова “очень" до “оч." и “хорошо” до “хор.", что является очень удачным решением, так как подобное сокращение распространено в русском языке и звучит естественно. Но иногда переводчица не сохраняет данную особенность при создании русского текста. Например, при переводе предложения "negative thoughts 942 (approx. based on av. per minute, minutes spent counting negative thoughts 127 (approx.)" переводчица использует такой вариант: “негативных мыслей - 942 (примерно, считая по их среднему количеству в минуту), минут, потраченных на подсчет негативных мыслей, - 127 (примерно)". Такое решение может быть обусловлено тем, что сокращения “прим." и “ср." могут быть восприняты читателями как слова "примечание" и "сравнительно", а не "примерно" и “средний", что привело бы к искажению смысла. Хотя во втором случае возможно было бы передать сокращение как “сред.”, что не дало бы утратить смысл сокращения и позволило бы сохранить его при переводе.

Ещё одним способом передать естественную манеру повествования, характерную для дневниковой прозы, является опущение частей речи. Хелен Филдинг часто опускает местоимения в тех случаях, когда Бриджит ведёт повествование от первого лица. При переводе Москвичёва передаёт это различными способами. Для перевода предложения: "Gotintotheoffice to find Perpetua had a bunch of flowers the size of a sheep on her desk." она прибегает к аналогичному приёму в русском языке и использует односоставное предложение: “Добраласьдоофиса и обнаружила, что 
Перпетуя получила букет цветов размером с овцу, и он стоит у нее на столе.” В некоторых случаях переводчица не сохраняет эту особенность и использует местоимение "я" в предложении. Например, “devices whichwillneveruse" она переводит как "которымия никогда не буду пользоваться". В другом случае для перевода предложения: “Quiteexcited, actually.” она также использует двусоставное предложение: "Я и впрямь очень волнуюсь.", например, хотя здесь можно было опустить местоимение и использовать вариант “Очень волнуюсь, на самом деле.” Удачным способом перевода может стать также безличное предложение как в случае с "Wonder if the post has come yet.", которое Москвичёва перевела как “Интересно, пришла ли уже почта." - этот вариант позволяет полностью передать эту особенность и является привычным для русскоязычных читателей.

Таким образом, можно сказать, что при переводе романа “Дневник Бриджит Джонс" А.Н. Москвичёва передаёт особенности этого произведения, для того чтобы сохранить его уникальность и индивидуальность. Авторский стиль Хелен Филдинг ярко проявляется именно в лексических особенностях текста, что не даёт возможности их игнорировать. Использование различных переводческих приемов позволяет переводчику создать адекватный текст на языке перевода, максимально приближенный к тексту оригинала, сохраняющий особенности авторского стиля писательницы

Поэтому переводчица А.Н. Москвичёва и постаралась донести их с помощью использования разных конструкций, так как без этого текст произведения потерял бы свою лёгкость и перестал бы выглядеть как личный дневник. Форма личного дневника очень сближает читательниц с главной героиней романа, что, несомненно, способствовало и способствует его успеху.

$$
* * *
$$

1. Романова Г.И. Практика анализа литературного произведения (русская классика): Учебное пособие. М.: Флинта, 2006. - 256 с.

2. Виноградов В. В. Проблема авторства и принципы атрибуции текстов неизвестного происхождения // Проблема авторства и теория стилей / В. В. Виноградов. - М.: Госуд. изд-во худ. лит., 1961. - С. 7-218.

3. Ефимов А. И. Стилистика художественной речи / А. И. Ефимов. - М.: Изд-во Моск. ун-та, 1961. $520 \mathrm{c}$.

4. Бахтин М.М. Эстетика словесного творчества. - М.: Искусство, 1979. - 424 с.

5. Пищальникова В. А. Проблемы лингвоэстетического анализа художественного текста: Учебное пособие / В. А. Пищальникова. - Барнаул: Изд. Алтайск. ун-та, 1984. - 59 с.

\section{Татевосян P.B. \\ Баллада Лермонтова "Тамара" в армянских переводах}

Армянский государственный педагогический университет имени Х.Абовяна (Республика Армения, Ереван)

doi: $10.18411 / s p c-26-03-2018-10$

idsp: 000001:spc-26-03-2018-10

\section{Аннотация}

В статье рассматриваются три перевода “Тамары” Лермонтова - Ал.Цатуряна, С.Вауни и Ф.Киракосяна.Вауни нередко нарушает последовательность строк, что меняет смысловые акценты. В переводе Ал. Цатуряна появляются дополнительные слова, эпитеты. Перевод Киракосяна лексически и интонационно ближе к оригиналу.

Ключевые слова: гибельная любовь, перестановка строк, перенос, рифмовка, краски, динамичность строки. 